\title{
Common Law, Statutes and Conservation Values: Do They Have Anything in Common?
}

\author{
by
}

\author{
Andrew Thompson 1
}

\begin{abstract}
Basic values in Canadian society are thought to be moving toward an expanded conservation ethic. There are two schools of thought. "Wise-use" conservation signifies management of forests and wildlife to maximize utilitarian values. "Preservationist" conservation is more concerned with intrinsic values in nature. Canadian common law and statutes are examined to determine what support they provide for "wise-use" conservation or a "preservationist" approach to resource management. Deficiencies are identified. Moreover, where statutes do impress on resource managers a duty to employ "wise-use" principles, noncompliance is often tolerated and Canadian courts are reluctant to hold public servants to the letter of the law. Integrated management is a precondition to making the trade-offs between forests and wildlife required by a "wise-use" policy, but by itself, provides no measure by which to make such trade-offs. "Wise-use" principles do provide such a measure, but their utilitarian emphasis invariably reduces wildlife to second place in competition with trees. If society wants to preserve intrinsic values in wildlife, the only alternative strategies available are raw potential power or charterlike laws that express clear principles of preservation. These laws would be society's choice in favour of arresting the deterioration in the natural environment documented in the World Conservation Strategy.
\end{abstract}

Key words: Resource, Conservation, Conservation policy, Conservation law, Integration.

John Livingston has challenged this symposium to reexamine basic values and assumptions about renewable resource use and management. My purposes are to try to identify these basic values and assumptions as they are exemplified in common law and statutes in Canada, and to ask what changes in law we should foresee as these basic values and assumptions undergo "paradigm variation," to use John Livingston's phrase.

If one can judge by responses to current issues of wildlife and forestry management, the paradigm variation that appears to be underway in Canadian society today is towards an expanded conservation ethic. For example, popular senti-

Professor of Law, Director, Westwater Research Centre, University of British Columbia, Vancouver, B.C. V6T 1W5 ment is steadily moving against predator control in British Columbia and Yukon and towards a conservation strategy that values nature for its own sake rather than just for harvesting. Combating acid rain is a popular cause even though it puts the value of healthy lakes and forests ahead of industrial development. In the case of forest management, the loudest cries are heard for reforestation with little regard for costbenefit considerations. That this support for conservation values seems to be surviving despite economic recession suggests that powerful forces calling for shifts in renewable resource management policies may lie around the corner of an economic turnabout.

Consequently, a review of Canadian common law and statute law to detect paradigm changes can best be conducted by examining what conservation values these laws now reflect.

One should not speak to "conservation values" as if the term expressed a single, uniform set of ideas about man's relationship to nature. Instead, modern attitudes toward the conservation of nature in North America can be divided into two main schools of thought. One, "wise-use" conservation, is identified historically with the pioneering work in natural resource management of Gifford Pinchot who became Chief Forester in the United States at the turn of the century. The other, "preservationist" conservation, draws its wellsprings from the inspirational writings and activities of John Muir during the same period. Pinchot's "wise-use" conservation focussed on the utilitarian values to be derived from nature in its provision of resources for man's use, and emphasized man's responsibility to use these resources as wisely and efficiently as possible. John Muir's followers, on the other hand, centred on intrinsic values in nature, holding that all living things have an inherent worth in the natural system and that man has a moral obligation to preserve this worth.

What measures should we expect to find in our judicial decisions and statute laws if they are to be seen as enshrining a conservation ethic? In the case of "wise-use" conservation, one would look for laws that encourage multiple-use perspectives and provide a foundation for achieving optimal resource use trade-offs. An enlightened system would recognize that the values expressed in conflicting demands to use resources cannot always be measured against each other in simple monetary terms, and therefore would provide means for taking nonpriced values into consideration. Unnecessary waste of resources would be prohibited. Even more, there would likely be a recognition that renewable natural resources are a heritage for future generations so that a sense of stewardship is owed not merely to avoid waste but to use resources on a sustaining basis. No one would be entitled to a monopoly. But 
those to whom the right to use a resource is allocated would be expected to use it beneficially. All these measures would be supported by effective administrative and enforcement systems.

If our common law and statute law provided nurture for a "preservationist" conservation ethic, we would expect to find quite different measures. Now we should not be looking for laws that structure an efficient market place so that resources are allocated to their highest utilitarian use. Rather, what we are trying to preserve are intrinsic values in nature that are likely quite uncompetitive with the values of "wise-use." Therefore, we should expect to find measures like those in a charter of rights. Instead of laws which recognize basic freedoms and rights for people notwithstanding that they occupy minority positions in society, we would have laws recognizing basic rights in nature notwithstanding that they may rank low on a utilitarian scale of values. These natural rights would be expressed in broad and general terms, as are human rights in the Canadian constitution. Principles stated in the World Conservation Strategy (IUCN 1980) such as preserving genetic diversity would provide an example. It would be the task of the courts to give these natural rights a concrete expression in day-to-day terms. If, for example, our charter of rights in nature enshrined a principle that all natural species are to be free from the danger of extinction, a program like the predator control of grizzly bears in Yukon could be challenged in court as a breach of this principle. It would then be the duty of the court to apply this principle to the facts and circumstances of the grizzly bear control program and to conclude whether the program was or was not a charter violation. The idea of such a charter of rights in nature is not so farfetched as might at first appear. Advocates of an environmental bill of rights have enjoyed some success in the United States. Michigan, for example, has enacted legislation that gives members of the public access to the courts to ensure that basic environmental standards are enforced. The famous National Environmental Policy Act, 1969 (NEPA) provides some fundamental legal protection of natural systems in requiring that environmental impact assessments must take into account long-term effects and alternatives with less impact on the environment

To what extent can Canadian common law and statute law be said to support either of these conservation ethics, and what portents of change are there in the legal system's approach to natural sytems?

\section{"Wise-use" Conservation}

If "wise-use"conservation is another name for the invisible hand of the market place, it is well served by the English common law which we have inherited. Legal remedies evolved hand-in-hand with the evolution of property rights. For those who could establish proprietary rights to land the common law provided actions for damages resulting from trespass or nuisance, and gave injunctive relief to prevent waste or other injury. Ownership of land normally included ownership of associated natural resources including rights to use water, to catch fish, to capture and kill wild animals, to cut trees, to plant and harvest crops, and to explore for and remove minerals or other profits of the soil.

This social arrangement should not be demeaned from a conservation viewpoint. Landowners in English common law exhibited a high sense of stewardship and of responsibility to pass on an undiminished heritage to future generations. Private ownership of forests, fish and wildlife provided inherent incentives to manage for optimum private use. If market place theory is correct, this optimization of private benefit aggregates to produce the greatest benefits for society as a whole. Certainly, it has been well argued by economists like Dale (1968) that the health of fishing streams in industrialized Britain can be attributed to the continued recognition of private property in the right to fish. The argument in more current form is made when the Weyerhauser Corporation is extolled for its wise forest management practices on the forest lands it owns in the Pacific Northwest.

Indeed, the economists argue that it is the very lack of private ownership that is the cause of wanton exploitation of natural resources. They call air and water "common property resources" to make the point that resources that are available to all comers without restriction are inherently subject to unrestrained exploitation as each harvester tries to keep up with his neighbor. The argument applies as well to the public lands and to their forests and wildlife if access and use are unrestrained.

In actual fact, the notion of a "common property resource" which no one owns and all are free to exploit has little basis in English or Canadian common law. Under the Canadian legal system, public lands and their resources have an owner, the state as represented by Her Majesty the Queen, either in the right of Canada or in the right of a province. In most respects this ownership represents the same characteristics as ownership by a private person. The Crown can gain the same remedies as a private owner for trespass to land or to restrain a nuisance, as where the Crown's water resources are wrongly polluted. For example, the Crown in British Columbia could have prevented Paul Watson from interfering with the wolf control program simply by giving him notice that his presence on Crown lands would be treated as a trespass.

In older jurisdictions (the early-settled parts of Ontario, for example) government policy was to transfer Crown ownership outright to settlers and commercial interests so that ownership of natural resources soon passed into private hands. Riparian rights to water and rights to fish still are attached to land ownership in parts of Ontario, Quebec and the Atlantic provinces. For these privately-owned natural resources, economic theory can still claim the socially-optimizing benefits of the free market based on the assumption that private individuals will seek to optimize their gains from resource ownership and that society overall will gain maximum benefits if all individuals are free to pursue such optimizing behaviour.

But in the parts of Canada that were settled and developed around the turn of the 19th century, the western provinces and the northern territories, government policy had changed so that private persons and corporations could gain only limited ownership rights in exploitable natural resources. The property in water, fish and wildlife was declared by statute law to have always been vested exclusively in the Crown. Private individuals could gain only such rights to use water or to fish and hunt as would be afforded by licensing systems subject to limited duration and heavily regulated in terms of methods of usage. Forests, petroleum resources and minerals would be granted only for limited terms with the Crown remaining the owner and having rights in the nature of a landlord in relation to the private forest and mining companies.

From the point of view of economic theory, could it now be assumed that the Crown would exhibit the same benefitmaximizing behaviour as the private owner of land and resources? There was good reason to question this assumption. The Crown as owner is not simply the aggregation of individual ownership interests but a new corporate interest whose behaviour and policies can not be explained in simple market-place terms. It might be more realistic to describe government as an aggregation of subgovernments. In terms of natural resources, we would identify these subgovernments as a forest ministry, a mines department or a fish and wildlife branch, each pursuing its own definition of social benefit. For example, the policies of a land branch of government may be to allocate Crown lands indiscriminately without any attempt to collect their economic rent; the policies of a mines branch 
may be to encourage mineral exploitation without regard to the costs imposed on other resource values; and the policies of a fisheries department may totally ignore the benefits of commercial development that are lost because of insistence on the protection of fish habitat.

Ownership behaviour in these cases is better explained by understanding that government, like large corporations, must incorporate a great variety of interests in its decision-making and that, for government, the overriding consideration is not a balance sheet but political survival.

Given these considerations, we cannot rest on an assumption that the Crown as owner of natural resources will be guided by an invisible hand to follow "wise-use" conservation principles. Instead, we must look for leadership in the legislation by which parliaments and legislatures define the goals, policies and practices that government departments are expected to pursue.

Consequently, to find "wise-use" conservation with respect to the Crown-owned land and resources in Canada, we must look to the statute law that defines the mandates for lands, forests, fish and wildlife departments to manage their respective resource sectors. Within these statutes we must look for provisions that recognize multiple-resource-use claims, that create systems which ensure that competing claims will be properly weighed and taken into account in trade-off situations, that prevent unnecessary waste, and that address issues of optimal benefits for society over time by ensuring that economic rents are captured and that exploitation rates do not discount future benefits too severely.

It is in this area that complaints about the inadequacy of the law in Canada are most frequently heard. It is said that resource management statutes tend to deal with resources on a piecemeal basis as if there were no interdependencies in nature. It is charged that they are implicitly biased towards development because they fail to state allocative principles or to define priorities of use. Hence they provide ready and unplanned access to whatever development interest happens to be first to stake a claim. These complaints can be readily documented. If "wise-use" conservation is a goal of government resource policy it is largely unexpressed. At the Westwater Research Centre we have recently completed an analysis of legislation in the Northwest Territories and Yukon for the federal Conservation Task Force (Rueggeberg and Thompson 1984). This shows how few natural resource management statutes have clearly stated objectives and priorities for protection, restoration and research, or carefully constructed provisions for monitoring and enforcement. In British Columbia some progress in these directions is being made. One may cite the Ministry of Forest Act and the Forest Act as statutes that explicitly state multiple-use objectives with respect to the forest resource.

More strident than complaints about the inadequacy of statutes are charges that governments don't enforce the "wise-use" rules that their statutes and policies do provide. When reforestration lags and fish habitat is degraded it is easy to fault public servants for failure to enforce policies that appear to be clearly stated in statute law.

This failure of public servants to implement the "wise-use" conservation policies available to them leads to the principle complaint that conservationists level against the courts. This complaint is that the courts are too reluctant to hold public servants to the letter of the law in the performance of their duties. If the government officer won't ensure compliance with effluent standards or compel a developer to live up to design undertakings when using public lands, why shouldn't the private citizen be entitled to come to court to enforce the law? But common law rules respecting standing to be a plaintiff, together with reluctance on the part of Canadian courts to intervene in the administration of policy by governments, are often bars to effective citizen action.

Are these charges about the inadequacy of judicial responses to conservation issues in Canada justifed? Certainly, if comparison is to be made with the frequency and variety of judicial interventions in administrative processes in the United States in the name of conservation, Canadian judicial interventions are inadequate. But may they ultimately be more effective by reason of their more discriminating nature?

I am slow to judge. On one hand there are still some technical limitations on standing to sue, though these can usually be overcome (see Thorne 1983). Substantive remedies remain difficult to identify because we have no equivalent as yet to the public trust doctrine that allows a US citizen in many states to sue to enforce laws respecting the public domain (see Rounthwaite 1982). Many remedies are barred on the basis that since a public wrong has been committed, only the attorney-general, representing the state, can bring an action. Finally, crushing cost awards can be a deterrent to the most stalwart of public-spirited citizens (Nova Scotia pesticide spraying case)

On the other hand, there are many examples of legal proceedings (or the threat of them) in Canada that have accomplished steadier resolve to implement the "wise-use" policies called for in statutes and regulations. From my own experience I can cite the British Columbia case of /slands Protection Society $v$. The Minister of Forests ([1979] 4 W.W.R. 1) and the threatened litigation by the Canadian Arctic Resources Committee to prevent the Department of Indian Affairs and Northern Development from issuing a land use permit for a port development in an area of the North Slope of the Yukon that had been withdrawn for conservation purposes. In addition, Canadian criminal law permits the private citizen to initiate prosecutions for offences under statutes like the federal Fisheries Act.

More significantly, I reserve judgment because I'm unconvinced that a more litigious society will be a wiser society in its use of natural resources. To the contrary, we at Westwater have been examining alternatives to strict penal enforcement of conservation laws - alternatives that would create more incentives for the private sector to implement sounder conservation practices. For example, negotiated conservation agreements, wherein developers undertake positive conservation programs could be offered as a comprehensive substitute for the multitude of development permits and licences that are now required. Water legislation could extend licences to include nonconsumptive conservation uses requiring the maintenance of water courses in their natural condition, as well as licensing for development purposes such as storage and diversion.

There are no easy answers as to how laws should be written to ensure wise management of natural resources. Our present state is one of beginning to define multiple-resource-use objectives and to deploy administrative means for accomplishing them. Much is yet experimental, as, for example, the onerous screening, assessment, and review practices that were put in place in the 1970s. Much more needs to be attempted in the way of monitoring and mitigation measures, and we must harness the self-interest of all who use natural resources to manage them well. The most fruitful development of all might be a positive response by industry to the move toward self-regulation now being introduced into the forests of British Columbia.

When so much remains to be done to provide a better foundation for "wise-use" conservation in the common law and statute law, it is obvious that our legal system remains far behind the aspirations of those who hold a "preservationist" 
view of conservation. We do have preservation statutes, such as the national and provincial parks statutes, and the ecological reserves legislation, but a charter of rights in nature seems far off. After all, we've only just achieved a charter of rights for persons.

One may ask whether it is important to aspire for laws that go beyond "wise-use" conservation. One may also ask what this examination of conservation ethics has to do with the underlying theme of this conference, which is to seek understanding as to how the management of forestry and wildlife can be better integrated. If by "integration" we mean only that policies and practices should be designed to avoid unnecessary harm to one natural resource by the exploitation of another, the importance of such "integration" is beyond question. But "integration" of resource management portfolios potentially means much more.

It is clearly a precondition of "wise-use" conservation, for, without such integration, the trade-offs cannot be made that are necessary if the mix of resource uses is to achieve optimum benefits for society. However, integration by itself provides no measure for these trade-offs. The principles of "wiseuse" conservation do, but their utilitarian emphasis invariably reduces wildlife to second place in competition with trees. Some Solomon's scale is needed if intrinsic values in wildlife are ever to overbalance the economic values of the forest. Nor is much comfort to be gained from the efforts of evaluation economists to find shadow prices for lost hunting opportunities to be weighed against the hard currency of timber sales.
If our society does value wildlife and their habitat for their own sake, and wishes to impose on governments and developers a mandate to preserve these values notwithstanding the higher economic values that harvesting the forests can provide, the only alternative to the exercise of raw political power is the enactment of charter-like laws that establish principles of preservation and strategies for achieving them. These laws may be seen as the embodiment of society's fundamental choices about its natural environment. I have spoken as if only wildlife were at stake. The forest lands are imperiled too, as industrialization and acid rain take their toll. Society must make its choices about the natural environment, for without clear choices in the laws governing natural resources, no degree of integration in management practices can arrest the deterioration in life support systems so clearly documented in the World Conservation Strategy (IUCN, 1980).

\section{References}

IUCN (International Union for the Conservation of Nature and Natural Resources). 1980. World Conservation Strategy. Gland, Switzerland. Portfolio and maps.

Dale, J.H. 1968. Pollution, Property and Prices. Univ. Toronto Press, Toronto, Ont. $111 \mathrm{p}$

Roundthwaite, I. 1982. The national parks: An endangered species Sask. Law Rev 46: 43

Rueggeberg, H. and A.R. Thompson. 1984. Conservation in the north: A legislative analysis. Westwater Res. Centre, Univ. British Columbia, Vancouver, BC. 50 p.

Thorne, G. 1983. Standing in the judicial review process. WCELRF Newsletter 8(2): 5 .

\title{
The Problems of Integrating Forestry and Wildlife Management: The Foresters' Viewpoint
}

\author{
by
}

M.R. Innes 1

\begin{abstract}
The long-established professions of biology and forestry harbour conscientious and intelligent practitioners. Communication between the two professions has traditionally been poor but is slowly improving. For integrated resource management to be successful, an acceptable planning framework must be established; there must be clearly enunciated and agreed-to objectives; cooperation between biologist and forester will be mandatory; and abnormally heavy commitment of time will be necessary. The cost of implementation will be a stumbling block.
\end{abstract}

Key words: Forestry, multiple use, integration, wildlife management.
'Manager of Forestry. Abitibi-Price Inc., Toronto-Dominion Centre, Toronto, Ontario M5K 1 B3

\section{Introduction}

The main problem with integration is that there isn't any. It just hasn't been happening. There are, however, examples of cooperative projects between forestry and wildlife jurisdictions and a brief examination of one of these with which I am familiar will help to uncover some of our traditional integration problems.

This cooperative project was that of modifying harvest patterns to assist moose management in northeastern Ontario. The government biologists approached Abitibi-Price with a carefully thought-out plan for modified cutting in Bragg Township. They explained that the local moose population was declining; that Bragg Township was an area of known moose concentration; that modified harvesting would provide winter cover, browse, and travel corridors; that a follow-up study would be done; and so on. All in all, it was a masterful job and a slick presentation. But beyond some comforting words in the forest management plan, moose management wasn't one of the company's objectives and the proposal was consequently politely declined on the basis that it would cost too much. The discouraged biologists returned to their maps, drastically 